\title{
Antitumor effects of anti-CD40/CpG immunotherapy combined with gemcitabine or 5- fluorouracil chemotherapy in the B16 melanoma model
}

\author{
Alexander Rakhmilevich*, Xiaoyi Qu, Mildred Felder, Zulmarie Perez Horta, Paul Sondel \\ From Society for Immunotherapy of Cancer 28th Annual Meeting \\ National Harbor, MD, USA. 8-10 November 2013
}

Our previous studies demonstrated that anti-CD40 mAb (anti-CD40) can synergize with CpG oligodeoxynucleotides $(\mathrm{CpG})$ to mediate antitumor effects by activating myeloid cells, such as macrophages in tumor-bearing mice. Separate teams have shown that chemotherapy with gemcitabine (GEM) or 5-fluorouracil (5-FU) can reduce tumor-induced myeloid-derived suppressor cells (MDSC) in mice. In this study we asked if the same chemotherapy regimens with GEM or 5-FU will enhance the antitumor effect of anti-CD40 and CpG. Using the model of B16 melanoma growing intraperitoneally in syngeneic C57BL/6 mice, we show that these GEM or 5 -FU treatment regimens either did not change or reduced, respectively, the number of MDSC in the peritoneal cavity of tumor-bearing mice. Treatment of mice with GEM or 5-FU did not significantly affect the antitumor function of macrophages as assessed in vitro. In vivo, treatment with these GEM or 5-FU regimens followed by anti-CD40/CpG resulted in antitumor effects similar to those of anti-CD40/CpG in the absence of GEM or 5-FU. Likewise, reduction of MDSC by in vivo anti-Gr-1 mAb treatment did not significantly affect anti-CD40/CpG antitumor responses. Together, the results show that the GEM or 5-FU chemotherapy regimens did not substantially affect the antitumor effects induced by anti-CD40/CpG immunotherapy.

Published: 7 November 2013

University of Wisconsin, Madison, WI, USA
doi:10.1186/2051-1426-1-S1-P86

Cite this article as: Rakhmilevich et al:: Antitumor effects of anti-CD40/ $\mathrm{CpG}$ immunotherapy combined with gemcitabine or 5- fluorouracil chemotherapy in the B16 melanoma model. Journal for ImmunoTherapy of Cancer 2013 1(Suppl 1):P86.
Submit your next manuscript to BioMed Central and take full advantage of:

- Convenient online submission

- Thorough peer review

- No space constraints or color figure charges

- Immediate publication on acceptance

- Inclusion in PubMed, CAS, Scopus and Google Scholar

- Research which is freely available for redistribution 